\title{
NOTES
}

\section{WALT WHITMAN AND ABRAM S. HEWITT: A PREVIOUSLY UNKNOWN CONNECTION}

On the inside cover of an important notebook in which Whitman drafted lines later used for new poems in the second edition of Leaves of Grass, the poet made the following note: "Hewetts pamphlet 'on the uses of iron." This obscure reference, written in tiny, barely legible script squeezed between entries in a list of New York street addresses, has not been explored by Whitman scholars, who have naturally been more interested in the many early lines for "Sun-Down Poem" (later "Crossing Brooklyn Ferry") and "Broad-Axe Poem" (later "Song of the Broad-Axe") contained in the same notebook. ${ }^{1}$ While researching for my recent book, Collage of Myself: Walt Whitman and the Making of Leaves of Grass, I tracked down Whitman's reference to "Hewetts pamphlet," hoping to find material Whitman used for "Song of the Broad-Axe." I eventually secured a copy of the "pamphlet," which turned out to be a transcript of a paper "read before The American Geographical and Statistical Society" at New York University by Abram S. Hewitt on February 21, $1856 .^{2}$

Hewitt's monograph, On the Statistics and Geography of the Production of Iron, doesn't contain any striking examples of Whitman's collage-like writing practice of stealing or adapting text for lines, but it does contain voluminous examples of "uses of iron" that may have served as general fodder for "BroadAxe Poem," as well as rhapsodic praise for iron and for the iron industry that recalls Whitman's own paean. Mainly, however, Hewitt's paper is a statistical analysis of international iron production, a prediction for the iron industry's future proliferation in the United States, and a defense against proposed tariffs on iron then being considered in Congress. His overall thesis seems to be that the growth of the iron industry occurs concordantly with overall growth of a civilization. Most interesting is the text's conclusion, where, after acknowledging that "the iron business has not been a successful and profitable branch of industry in this country, if measured by the rewards it has brought to those who have carried it on," Hewitt offers consolation to unprofitable ironmasters by quoting an "eccentric," unnamed poet:

Have you heard that it was good to gain the day?

I also say it is good to fail-battles are lost in the same spirit as they are won.

I sound triumphal drums for the dead-I fling through my embouchures the loudest and gayest music to them-

Vivas to those who have failed, and to those whose war vessels sank in the sea,

And to all generals that lost engagements, and all overcome heroes, and the numberless unknown heroes equal to the greatest heroes known. (35-36) 
These lines, an inexact excerpt from the poem eventually entitled "Song of Myself," reveal that Hewitt must have read Whitman prior to composing the text for this speech and was impressed enough to include his poetry in his first major public lecture, which also became his first published monograph. There are a number of fascinating implications to this for Whitman scholarship and nineteenth-century literary history — some speculative, some definite. For one, Whitman's reference to Hewitt in the "George Walker" notebook indicates the notebook was still in use after Hewitt's pamphlet was published in 1856, which helps to date to notebook's contents. ${ }^{3}$ It is also further evidence that Whitman's writing process was often informed by research. Indeed, on the bottom of the same leaf, Whitman lists other sources that might have served as material for his lines and references, including a "Map of Mountains \& Rivers," that apparently was available "wholesale" for "90 cts" at a store on Nassau Street; a vaguely described "map of the world"; and a publication Whitman referred to as "The world's standards \& costumes / charts [writing illegible] sheets."

Perhaps more interesting, however, is the fact that someone like Abram S. Hewitt would quote Whitman at all, especially as early as February of 1856. Today, Hewitt is remembered as a former mayor of New York City (sometimes referred to as the "father of the NewYork subway system"), a U.S. Congressman, and as a long-time steward of the board of trustees for the Cooper Union in Manhattan. ${ }^{4}$ In 1856, he was none of these things, but he was already a highly successful entrepreneur, running one of the country's largest iron manufacturing plants in Trenton, New Jersey. He had also co-founded The American Telegraph Company along with others including telegraph and Morse code co-inventor Samuel F. B. Morse. ${ }^{5}$ As the close confidant, business partner, and recently betrothed son-in-law of Peter Cooper, Hewitt was also a part of one of New York's wealthiest and most important families. ${ }^{6}$ In short, when Hewitt quoted Whitman to his lecture audience in 1856 , Hewitt was already entrenched in the very highest echelon of New York City's financial and cultural elite. Furthermore, according to Hewitt's biographer, Peter Cooper himself was an official member of the society to which Hewitt delivered his address, and Cooper likely attended the lecture and heard Hewitt quote from Leaves of Grass-a book that had been in print for less than seven months. ${ }^{7}$ As far as I have been able to determine, this is the first time someone used Whitman's lines in print for a purpose besides a book review.

This shows that Leaves of Grass was successful in securing some rather important readers for its early audience, and not all of them were directly solicited, like Emerson. ${ }^{8}$ Certainly, the first edition of Leaves of Grass was more successful than Whitman indicated it was later in his career, when he was fond of portraying himself, as so many other writers have portrayed themselves (legitimately or not), as neglected and beleaguered. That someone like Abram S. Hewitt was reading Whitman and was struck by him enough to quote him before a gathering of some of the most powerful and important men in New York demonstrates the range of Whitman's early appeal as a poet. Very shortly after publishing his first book of poetry, he found an audience in perhaps the single most important taste-maker of the day in Emerson, as well as in the elite financial and political leaders of New York City, as exemplified by Hewitt and Cooper. Hewitt's use of lines from "Song of Myself" adds to a growing body of evidence, including 
the recently discovered daguerreotype of a young woman proudly displaying her copy of the 1856 edition, ${ }^{9}$ that Leaves of Grass was as successful of a first book of experimental poetry as could have plausibly been hoped. ${ }^{10}$

Hewitt's quote itself, which differs in many ways from the way the poem was published in the first edition, is also interesting, as it contains many changes from the only previously published version - so many that these differences do not seem accidental. Whitman's ellipses within lines, so prevalent in the first edition, have been replaced with em-dashes or commas, as they would be in the second edition of Leaves of Grass - only the second edition of Leaves of Grass had not yet been published. In the second quoted line "fail" has been substituted for "fall," and "as they" has replaced "in which they." Most striking of all, an entire phrase, "and those themselves who sank into the sea," has been omitted from the fourth quoted line. As far as the known record shows, no version of these lines was ever published by Whitman that matches Hewitt's quotation, which begs the question of how the lines came to be the way they are in Hewitt's monograph on iron. It is possible that Hewitt simply misquoted Whitman, and the changes are accidental. If so, this would be quite out of character. Known as a meticulous man, Hewitt (who frequently quoted literary figures he admired) did not misquote Virgil, Shakespeare, Whittier, William Cullen Bryant, or Samuel Johnson when he cited them elsewhere in his published writing. ${ }^{11}$ It seems doubtful that changes this significant were accidental.

Was Hewitt trying to improve upon the novice poet he was quoting by editing a few things for an audience he could be confident wouldn't notice? Was he quoting from a review or publication in journalism that has now been lost? Did he hearWhitman read from his work somewhere and attempt to write the lines down? Had he received an alternate version from the poet himself? Pending further evidence, we can only guess at the answers to such questions. One thing we can be sure of is that within seven months, Whitman's poetry had already penetrated to one of the most respected halls of academia, receiving immediate audience with the professors and capitalists that his lines famously scorned.

Yeshiva University

Matt Miller

\section{NOTES}

1 The notebook, referred to by scholars as the "Crossing Brooklyn Ferry Notebook" or "George Walker" (the first legible words therein), is located in the Feinberg Collection at the Library of Congress (item number 697). A transcription is available in Walt Whitman, Notebooks and Unpublished Prose Manuscripts, ed. Edward F. Grier (New York: New York University Press, 1984), 1:226, 233.

2 Abram S. Hewitt, On the Statistics and Geography of the Production of Iron (New York: W.C. Bryant \& Co., 1856), 3.

3 I have been unable to determine the exact date of publication for Hewitt's paper, though it must have been long enough after the speech was originally given on February 21,1856 , to allow for publication time and before December, 1856, when a revised version (which did not contain the Whitman excerpt) was published by DeBow's Review. See Abram S. Hewitt, "Statistics and Geography on the Production of Iron," Debow's Review 21 (1856), 578-589. 
4 “Abram S. Hewitt," The Encyclopedia of New York City, Second Edition, ed. Kenneth T. Jackson (New Haven, CT:Yale University Press, 2010), 594.

5 Edwin G. Burrows and Mike Wallace, Gotham: A History of New York to 1898 (New York: Oxford University Press, 1999), 662, 775.

6 Edward C. Mack, Peter Cooper: Citizen of New York (New York: Duel, Sloan and Pearce, 1949), 174.

7 Allan Nevins, Abram S. Hewitt:With Some Account of Peter Cooper (New York: Harper and Brothers, 1935), 138-139.

8 The fact that Whitman misspelled Hewitt's name and did not refer to him in any known correspondence suggests they were not acquainted, nor is there evidence the poet reached out to Hewitt as he did with Emerson. And why would he, especially in 1855, when Hewitt was only known, if he was known at all, as a talented entrepreneur in the iron industry and lucky husband of Amelia Cooper?

9 Ed Folsom, "The Sesquicentennial of the 1856 Leaves of Grass: A Daguerreotype of a Woman Reader," Walt Whitman Quarterly Review 24 (Summer 2006), 33-34.

10 The fact that Whitman had published a handful of immature poems over seven years earlier in various local newspapers hardly explains the immediate success of Leaves of Grass.

11 Abram S. Hewitt, Selected Writings of Abram S. Hewitt (New York: Columbia University Press, 1937), 13, 224, 296, 311, 320.

\section{A RECENTLY DISCOVERED PHOTOGRAPH OF FRED GRAY}

The photograph of Walt Whitman's comrade John Frederick Schiller Gray (Fred Gray), first published in a volume of Civil War reminiscences and reproduced here, is a previously unknown image of Gray, a college student turned Union soldier whom the poet met at Pfaff's beer cellar in New York during the summer of 1862, a few months before Gray enlisted. Whitman spent nearly every evening with the young man at Pfaff's, forming lasting comradeships with Gray and the other members of a group of educated and well-traveled bachelors that the poet called the "Fred Gray Association." Before beginning his military service, Gray gave Whitman a prized copy of Frederic Hedge's Prose Writers of Germany as a parting gift. Inside this volume, the poet kept two card photographs of Gray in his military uniform-one of which was dated September 3, 1862, only three days before Gray was mustered into service as a second lieutenant in the Twentieth New York Infantry Volunteers. ${ }^{2}$ These photographs, which Whitman carefully preserved, were the only known extant images of Gray until my recent discovery of this picture of the twenty-twoyear-old soldier during his time on the staff of Major-General John Ellis Wool.

This photograph of Gray, along with another image showing the remaining members of Wool's personal staff, was published in an 1895 book entitled Personal Reminiscences of the Rebellion, 1861-1866 by Le Grand Bouton Cannon. ${ }^{3}$ When he was eighty years old, Cannon, who had been a capitalist and a "director in numerous banking and industrial corporations," set to work 